\title{
Effective control of neem (Azadirachta indica A. Juss) cake to plant parasitic nematodes and fungi in black pepper diseases in vitro
}

\author{
Tác động của bánh dầu neem (Azadirachta indica A. Juss) lên tuyến trùng và \\ nấm bệnh ký sinh cây hồ tiêu ở điều kiện in vitro
}

Research article

Duong, Duc Hieu ${ }^{1 *}$; Ngo, Xuan Quang ${ }^{1}$; Do, Dang Giap ${ }^{1}$; Le, Thi Anh Hong ${ }^{1}$; Nguyen, Vu Thanh ${ }^{2}$;ic Smol ${ }^{3}$

${ }^{1}$ Institute of Tropical Biology, Vietnam Academy of Science and Technology (VAST). 9/621 Hanoi highway, Linh Trung ward, Thu Duc district, HCM City, Vietnam; ${ }^{2}$ Institute of Ecology and Biology Resources, VAST. 18 Hoang Quoc Viet, Cau Giay, Hanoi, Vietnam; ${ }^{3}$ Postgraduate International Nematology Course, Vakgroep Biologie, Ledeganckstraat 35, B-9000 Gent, Belgium

\begin{abstract}
Neem cake is a product of the cold pressing from the neem kernels to obtain neem oil. Bio-active substances from neem cake extracted solutions were evaluated for their potential to control the root knot nematodes and other pests of plants. In this study different concentrations of the solution extracted from neem cake was tested against the second stage juveniles of the plant parasitic nematode Meloidogyne spp. and four phytopathogenic fungi: Rhizoctonia solani, Sclerotium rolfsii, Collectotrichum spp. and Phytopthora capsici. Toxicity of neem cake extractions is represented by the $\mathrm{EC}_{50}$ value for the second-stage juvenile (J2) of Meloidogyne spp. and the four phytopathogenic fungi via Probit analysis. A 5\% dilution of the solvent extracting from neem cake already caused $100 \%$ larval mortality after 24 hours exposure. Undiluted neem cake extraction effectively inhibited the growth of the four phytopathogenic fungi. The $\mathrm{EC}_{50}$ value of neem cake on J2-larvae of Meloidogyne nematode and on the fungi Rhizoctonia solani, Sclerotium rolfsii, Collectotrichum spp. and Phytophthora capsici was $0.51,0.74,0.30,0.51$ and $4.33 \%$, respectively.
\end{abstract}

Bánh dầu neem là sản phẩm của quá trình ép nhân hạt neem để lấy dầu. Các hoạt chất sinh học tùr dịch chiết bánh dà̀u neem đã được đánh giá có tiềm năng lớn trong phòng trù̀ tuyến trùng nốt sung và các loài dịch hại khác của nhiều loại cây trồng. Trong nghiên cứu này các nồng độ dịch chiết khác nhau của bánh dầu neem đã được thử nghiệm khả năng diệt tuyến trùng (ấu trùng tuổi 2 thuộc giống Meloidogyne spp.) và úc chế 4 loài nấm bệnh nhu: Rhizoctonia solani, Sclerotium rolfsii, Collectotrichum spp. và Phytopthora capsici. Độc tính của dịch chiết bánh dầu neem được biểu diễn bởi giá trị $E C_{50}$ đối với ấu trùng tuổi 2 của tuyến trùng Meloidogyne spp. và các loài nấm bệnh thông qua phân tích Probit. Dịch chiết bánh dầu neem ở nồng độ 5\% đã làm chết 100\% cá thể IJ2 của Meloidogyne spp sau 24 giờ phơ nhiễm. Dịch nguyên chất bánh dầu neem ức chế cả 4 loài nấm bệnh. Giá trị EC $C_{50}$ của bánh dầu neem lên ấu trùng tuổi 2 của Meloidogyne spp và các loài nấm bệnh Rhizoctonia solani, Sclerotium rolfsii, Collectotrichum spp. and Phytophthora capsici tưong úng là $0.51,0.74,0.30,0.51$ và $4.33 \%$.

Keywords: neem cake, biocontrol, root knot nematode, anti-fungal activity, plant extracts, phytopathogenic fungi, Meloidogyne spp.

\section{Introduction}

Plant parasitic nematodes cause great economic losses to agricultural crops worldwide. Among them root-knot nematode, especially the genus Meloidogyne are most harmfull in the tropics to many plants, such as black pepper trees. In the past only chemicals were usedas nematicides. However, the abuse of chemical pesticides has 
negative impact on the beneficial insects as well as on human health (Vu Dang Khanh, 2003). Therefore, to conserve and establish an agricultural system with ecological sustainability, it is necessary to develop biological methods to not only control the nematode populations, but also to ensure productivity, quality of plants and to reduce environmental pollution.

Neem cake is the residual part of the process to compress the neem seeds to obtain oil and it is considered as a source of useful organic fertilizer. This kind of fertilizer not only provides nutrition for plants but also controls the root-knot nematodes. Moreover, neem cake can be used as inhibitors to control many species of pathogenic fungi (Singh et al., 1984; Sartaj et al., 1995; Vu Trieu Man and Le Luong Te, 1998; Farooq et al., 2008).

Currently neem cake and many other derivates are used for controlling plant parasitic nematode (Musabyimana T., and R.C. Saxena, 1999; Nazir et al., 2007). Many publications showed that the biological activity of neem cake has the ability to reduce the populations of root-knot nematodes, such as Meloidogyne incognita in the soya plant and Meloidogyne javanica in both tomato and and soya trees. The powder of neem seeds are also used to control Meloidogyne arenaria and Pratylenchus penetrans in tomato plants. Some authors also experimented on neem cake mixed with other materials such as wheat straw, sawdust and NPK fertilizer to control root-not nematode effectively (Ramarao P., Usharaja, 1983; Randhawa N.S, B.S. Parmar, 1996).
Hence this study aims to evaluate the effect of neem cake for controlling root-not nematode in Vietnam and its antagonistic potential against phytopathogenic fungi.

\section{Materials and methods}

\subsection{Materials}

\subsubsection{Preparation of neem cake extracted solutions}

Fresh seeds were collected from ripe fruits harvested from 4 years old neem (Azadirachta indica A. Juss) trees growing in Ninh Thuan province, Vietnam then cleaned and dried in the shade to $10-15 \%$ moisture content. The dried neem seeds were transferred to the Experimental Laboratory of the Institute Tropical Biological, where the seeds were separated from the pellets. Neem cake and neem oil were obtained simultaneously by using cold-pressing vegetable oil machine (KOMET Model D 85 - 1G, Germany) from compressing neem seed kernel. A part of the neem oil was used to produce bio-pesticides, and the rest part was used as material for this study.

100 grams of neem cake was grinded and soaked into 200 $\mathrm{ml}$ alcohol $96^{\circ}$ for 4 hours and then extracted by filtering the solution 4 times through the sterilized millipore $0.45 \mu \mathrm{m}$ filter, the rest was discarded. All filtrations were mixed up together and vacuum extracted by rotation of the obtaining solution $100 \mathrm{ml}$ was taken as neem enrichment extract (NEE) for testing. This extracted solution was used undiluted and diluted with pure sterilized water to the following concentrations: $2.5,5,10$ and $20 \%$ (Vu Van Do, 2007).
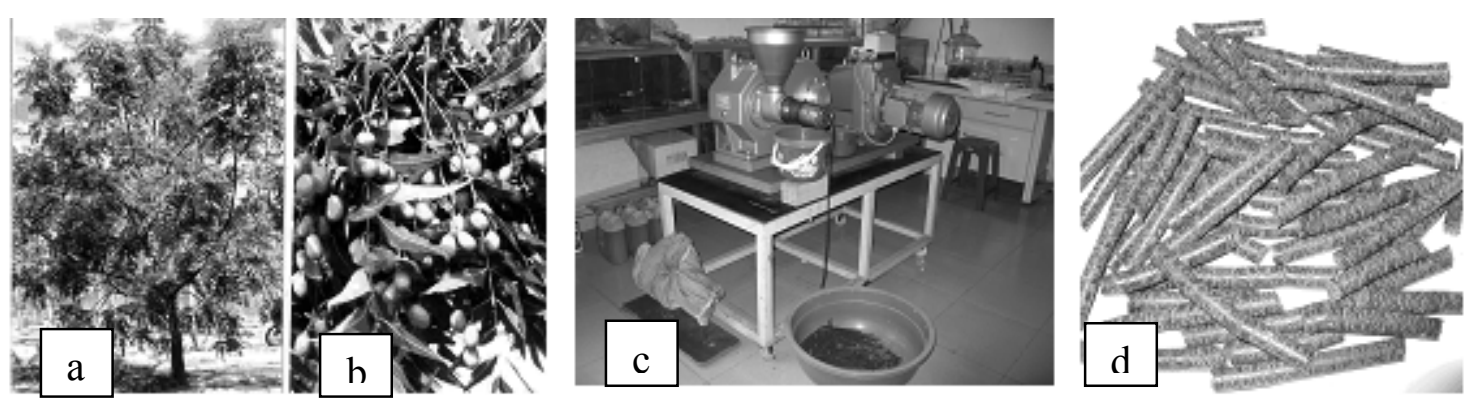

Figure 1. a) Neem tree planted in Ninh Thuan, Vietnam; b) neem fruits; c) cold-pressing machine; d) neem cake obtained by cold-pressing via Komet (Germany)

\subsubsection{Extraction of juveniles}

The second stage juveniles of Meloidogyne spp. were extracted from the roots of black pepper plants in Thuan Hanh village (Dak Song district, Dak Nong province) by modified Baermann tray extraction method using sieves with $0,5 \mathrm{~mm}$ mesh size put into petri dish (diameter $90 \mathrm{~mm}, 15 \mathrm{~mm}$ high) with soft papers on it. Clean roots of black pepper were put on the sieve and water was added to the level of submerging the roots. The petri dish was covered and put into the incubator room during 48 hours at $28^{\circ} \mathrm{C}$. The living nematodes penetrated through the sieve and settled down at the bottom of the petri dish (Nguyen Ngoc Chau, 2003; Coyne et al, 2007).

\subsubsection{Pathogenic fungi}

Four species of phytopathogenic fungi: as Rhizoctonia solani, Sclerotium rolfsii, Collectotrichum spp. and Phytopthora capsici were received from Department of Plant Protection (Ho Chi Minh Agricultural and Forest University) and was maintained in PGA until needed.

\subsection{Methods}

\subsubsection{Root knot nematode bioassay}


Ten millilitre of the undiluted and the following concentrations: $2.5,5,10$ and $20 \%$ of neem cake extract were separately poured into petri dishes and $1 \mathrm{ml}$ of suspensions containing about $20 \mathrm{~J} 2$ individuals were added to each petri dish. All treatments were replicated three times. The petri dishes were incubated at room temperature. Percent mortality was calculated after 6, 24 and 48 hours. All the data collected were analyzed using analysis of variance and means separated with the Least Significant Difference Test in a MSTATC software.

\subsubsection{Fungi bioassay}

PGA (Potato Glucose Agar) medium was used for maintaining the cultures on sterile petri dishes. The undiluted and each dilution of neem cake extracted solutions were passed through a membrane filter $(0.45 \mu \mathrm{m}$ dimension $)$ to avoid any bacterial and fungal contamination, then $1 \mathrm{ml}$ of the test extraction solution is transferred to the sterilized dish and $20 \mathrm{ml}$ of the molten PGA medium $\left(45^{\circ} \mathrm{C}\right)$ is added, and this mixture combining solution in the PGA medium is kept at cool temperature. PGA medium without neem cake extraction solution is used as the control. A uniform fungal mycelium is obtained by introducing a 5mm-diameter stainless-steel cork borer into the center of the petri dish. Each treatment is replicated three times. The plates were incubated at room temperature for 4 days. After the incubation period, two perpendicular diameters of the fungi were linearly measured in $\mathrm{mm}$ and the mean diameter was calculated. The percentage of growth inhibition was calculated as:

The percentage of growing inhibition $=\frac{D c-D t}{D c} \times 100$

In which:
$D_{c}$ : the average colony diameter of fungi in the control experiment.

$\mathrm{D}_{\mathrm{t}}$ : the average colony diameter of fungi in the treatment experiment.

\subsubsection{Data process}

The mortality rate of Meloidogyne spp. second stage juveniles was determined after every hour as well as the percentage of growing inhibition of the fungi. The $\mathrm{EC}_{50}$ for nematodes and the $\mathrm{IC}_{50}$ for fungi was calculated by the method of Probit analysis, the data were processed via the Microsoft Excel (Nguyen Ngoc Kieng, 1992).

\section{Results and discussion}

\subsection{The effect of neem cake on the Meloidogyne spp. second stage juveniles}

Table 1 shows that most of the Meloidogyne spp. second stage juveniles already died after 6 hours when using 5\% or more of the neem cake extracted sollutions and was $100 \%$ at $10 \%$ or more of the extracted sollution. The mortality of Meloidogyne spp. second stage juveniles is $87 \%$ and $100 \%$ after 6 hours and 24 hours exposed in 5\% concentration, respectively. At $2.5 \%$ concentration, the mortality of Meloidogyne spp. second stage juveniles was nearly $80 \%$ after 48 hours. These results indicate that neem cake extracted solution is very effective to control the root-not nematodes. In fact, neem cake containing the biological substance (azadirachtin, salannin, nimbin) and its derivative compound belonging to the group of triterpenoid, limonoid, etc. have been proven to contain strong toxicity for plant parasitic nematode (Keshav et al., 1996; Nazir Javed, 2008; Adegbite A.A., and S.O.Adesiyan, 2005) but do not harm the beneficial microorganism in the soil (Muhammad Abid, 1996).

Table 1. Percentage of $\mathbf{J} 2$ mortality in testing with neem cake extracted solution

\begin{tabular}{llcc}
\hline $\begin{array}{l}\text { Concentration of neem cake } \\
\text { extracted solution }(\%)\end{array}$ & \multicolumn{3}{c}{ The second stage juveniles mortality (\%) after } \\
\cline { 2 - 4 } 0 (control) & $\mathbf{6}$ hours & $\mathbf{2 4}$ hours & $\mathbf{4 8 ~ h o u r s}$ \\
2,5 & $0,00 \pm 0,00 \mathrm{~d}$ & $0,00 \pm 0,00 \mathrm{c}$ & $0,00 \pm 0,00 \mathrm{c}$ \\
5 & $24,17 \pm 0,76 \mathrm{c}$ & $63,0 \pm 0,87 \mathrm{~b}$ & $77,83 \pm 2,57 \mathrm{~b}$ \\
10 & $87,5 \pm 1,26 \mathrm{~b}$ & $100 \pm 0,00 \mathrm{a}$ & $100 \pm 0,00 \mathrm{a}$ \\
20 & $100 \pm 0,00 \mathrm{a}$ & $100 \pm 0,00 \mathrm{a}$ & $100 \pm 0,00 \mathrm{a}$ \\
100 & $100 \pm 0,00 \mathrm{a}$ & $100 \pm 0,00 \mathrm{a}$ & $100 \pm 0,00 \mathrm{a}$ \\
\hline CV $(\%)$ & $100 \pm 0,00 \mathrm{a}$ & $100 \pm 0,00 \mathrm{a}$ & $100 \pm 0,00 \mathrm{a}$ \\
LSD & 0,83 & 0,31 & 0,00 \\
\hline Th & 1,227 & 0,523 & - \\
\hline
\end{tabular}

The percentage was transformed to arcsin $(x)^{1 / 2}$ before using for statistical process. Other characters after data column show the significant difference with $p \leq 0.01$ by ranking $L S D$.

Compared to Adegbite et al. (2005), our results are much better: larval mortality already occurs at $5 \%$ concentration after 6 hours, whereas in the experiment of Adegbite et al (2005) larval mortality only is observed at $100 \%$ concentration or undiluted neem cake extractions. The other level of concentration like $20 \%, 10 \%$ and $5 \%$ leads to reduction of the larval mortality percentage from $90 \%$ to $1.7 \%$. In the meantime, neem cake extracts from Ninh Thuan, Vietnam kill almost of second-stage juveniles at the level of concentration $10 \%-100 \%$, even at $5 \%$, in the time of 24 hours or 48 hours. At the level lower than 5\% $(2.5 \%)$, it also controls 2 nd Juvenile effectively with the percentage of mortality from $24,17-77,83 \%$ in 6,24 and 48 hours.

This means that neem cake extracted solution from neem (Azadirachta indica A. Juss) tree originating from Ninh 
Thuan, Vietnam can be very useful as bio-control method against Meloidogyne spp. second stage juveniles.

\subsection{The anti-fungal activity of neem cake extracted solutions on pathogenic fungi}

Data in table 2 show that the phytopathogenic fungus Rhizoctonia solani was already inhibited by $17 \%$ dilution of NEE: Water (1:30), and original undiluted extracted solution inhibits completely R. solani $(100 \%)$.

Table 2. The radial growth diameter $(\mathrm{mm})$ and inhibition percentage of fungi (\%): $R$. solani, S. rolfsii, Collectotrichum spp. and Phytophthora capsici by neem cake extracted solutions

\begin{tabular}{|c|c|c|c|c|c|c|}
\hline & \multicolumn{5}{|c|}{ The percentage of neem cake extracted solution (\%) } \\
\hline & & Control & NEE & $\begin{array}{c}\text { NEE:water } \\
(1: 10)\end{array}$ & $\begin{array}{c}\text { NEE:water } \\
(1: 20)\end{array}$ & $\begin{array}{c}\text { NEE:water } \\
(1: 30)\end{array}$ \\
\hline \multirow[t]{2}{*}{ Rhizoctonia solani } & Radial growth diameter (mm) & 90 & 0 & 55 & 70 & 75 \\
\hline & Inhibition percentage $(\%)$ & 0 & 100 & 39 & 22 & 17 \\
\hline \multirow{2}{*}{$\begin{array}{l}\text { Sclerotium } \\
\text { rolfsii }\end{array}$} & Radial growth diameter (mm) & 90 & 0 & 28 & 30 & 58 \\
\hline & Inhibition percentage $(\%)$ & 0 & 100 & 69 & 67 & 36 \\
\hline \multirow{2}{*}{$\begin{array}{l}\text { Collectotrichum } \\
\text { spp }\end{array}$} & Radial growth diameter $(\mathrm{mm})$ & 40 & 2 & 15 & 22 & 27 \\
\hline & Inhibition percentage $(\%)$ & 0 & 95 & 62.5 & 45 & 32.5 \\
\hline \multirow{2}{*}{$\begin{array}{l}\text { Phytophthora } \\
\text { capsici }\end{array}$} & Radial growth diameter $(\mathrm{mm})$ & 55 & 18 & 40 & 60 & 60 \\
\hline & Inhibition percentage (\%) & 0 & 67 & 27 & 0 & 0 \\
\hline
\end{tabular}

Notes: NEE - neem enrichment extract; NEE:water - dilution of neem cake extracted solution with ratio 1:10, 1:20 and 1:30.

For Sclerotium rolfsii, has a characteristic growth by white fibers spreading out as rays around and it covers almost the petri dish surface only after 4 days (Figure 2). The inhibiting effect of dilution extracted solution NEE:water at $1: 30$ and 1:10 concentrations was respectively $36 \%$ and $69 \%$. The ability of $100 \%$ inhibition of the NEE solutions was also found. According to Ramarao (1983) besides neem cake, extracted solution from castoroil plant and groundnut cake are also good to use for controlling the fungus $S$. rolfsii on the wheat plants.

With regard to the phytopathogenic fungus, Collectotrichum spp. grows by forming suckers in the host and the speed of development is rather low (Figure 2). The corresponding inhibiting effects are $32 \%, 45 \%$ and $62 \%$ with a dilution rate of NEE:water being 1:30, 1:20 and 1:10 respectively. Original extracted solution (NEE) can inhibit this type of fungus up to $95 \%$.

Figure 2 shows that Phytopthora capsici grows and creates patches of cobweb or star colonies, growing quite slowly compared to other types of disease fungi. However, the inhibiting effect of undiluted neem cake is only $67 \%$ and the inhibiting effect diminishes at lower concentrations becoming $27 \%$ at the dilution of NEE: water being 1:10 and further dilutions have not any inhibiting effect. This result corresponds to the findings of Jeyarajan et al. (1987), besides Phytopthora capsici, they also evaluate the difference of additional compost, sawdust and neem cake on land against Fusarium solani causing root rotten disease in the green bean plants. Singh and Vyas (1984) also studied the influence of some kinds of pressure cakes as mustard plant, castor-oil plant, neem and mahua to Phytophthora parasitica and P. piperina. The results showed that almost all of the pressure cake inhibits growth of those phytopathogenic fungi.

Study results show that neem cake inhibits the growth of Sclerotium rolfsii most effectively, followed by $R h i$ zoctonia solani and Collectotrichum spp. The growth rate of phytopathogenic fungus Phytopthora capsici is only slightly inhibited by neem cake.
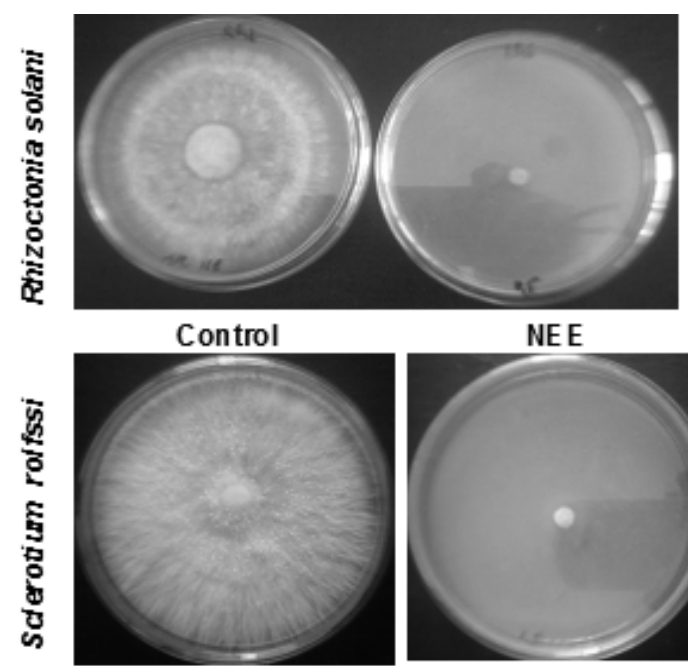

Control
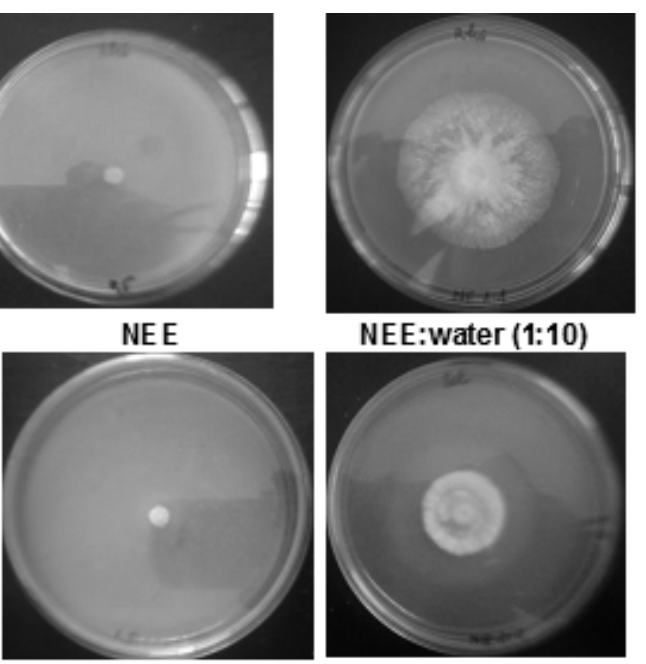

NEE
NEE:water (1:10)

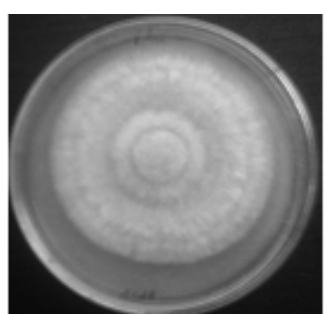

NEE:water (1: 20)

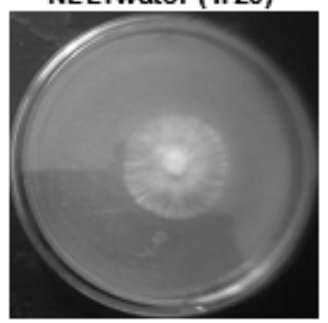

NEE:water (1: 20)

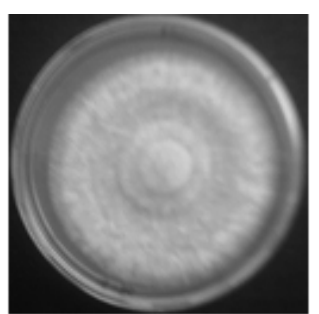

NEE:water (1:30)

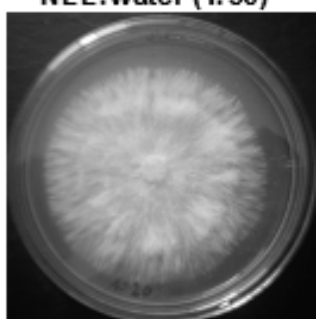

NEE:water (1:30) 


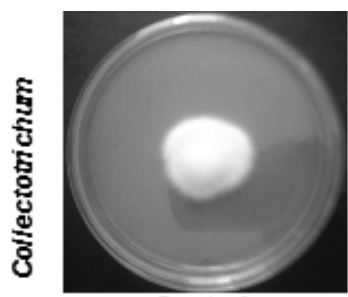

Control

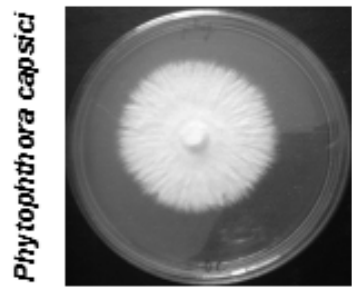

Control

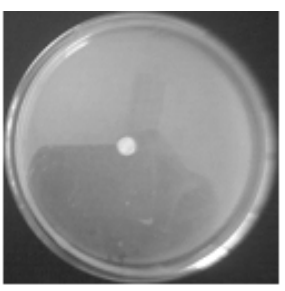

NEE

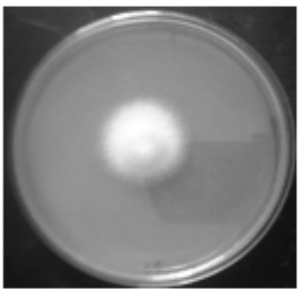

NEE

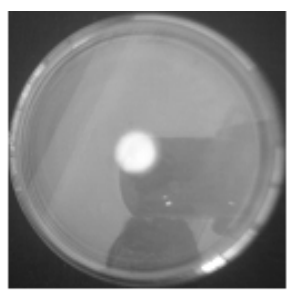

NEE :water (1:10)

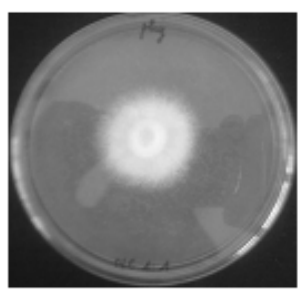

NEE :water (1:10)

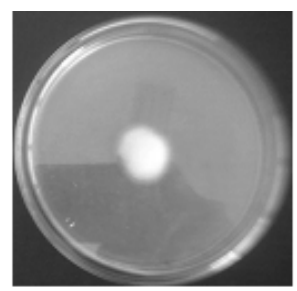

NEE:water (1:20)

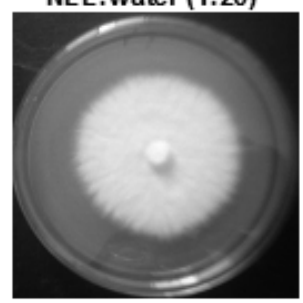

NEE:water (1:20)

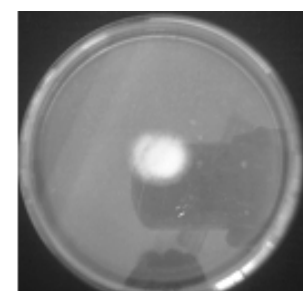

NE E:water (1:30)

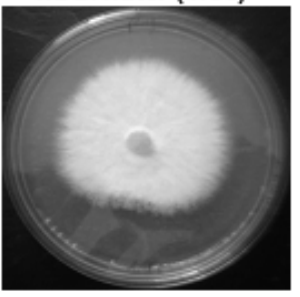

NE E: water (1:30)

Notes: NEE - neem en richment extract, NEE:water - dilution of neem cake extracted solution with ratio 1:10, 1:20 and 1:30.

Figure 2. The effect of different concentrations of neem cake extracted solution on the growth of Rhizoctonia solani, Sclerotium rolfsii, Collectotrichum spp. and Phytophthora capsici

\subsection{The value $\mathrm{EC}_{50}(50 \%$ Effect Concentration) of neem cake}

The $\mathrm{EC}_{50}$ value is an important parameter to evaluate the toxicity level of neem cake extracted solution on second stage juveniles of the root-knot nematode Meloidogyne and the phytopathogenic fungi Rhizoctonia solani, Sclerotium rolfsii, Collectotrichum spp. and Phytophthora capsici.

$\mathrm{EC}_{50}$ values are presented in Table 3.

Table 3. Value $\mathrm{EC}_{50}$ of neem cake extracted solution on second stage juveniles and pathogen fungi

\begin{tabular}{lllcc}
\hline & & $\begin{array}{l}\text { Statistic function } \\
(\mathrm{Y}=a+\mathrm{bX})\end{array}$ & $\begin{array}{c}\text { Correlation } \\
\text { coefficient }(\mathrm{R})\end{array}$ & $\begin{array}{c}\text { Value EC } \\
(\mathrm{gram} / 100 \mathrm{ml})\end{array}$ \\
\hline Meloidogyne spp. & After 6 hours & $\mathrm{Y}=-6.92338+6.253031 \mathrm{X}$ & 0,99 & 0,81 \\
second stage & After 24 hours & $\mathrm{Y}=-11.2162+9.207056 \mathrm{X}$ & 1,0 & 0,58 \\
juveniles & After 48 hours & $\mathrm{Y}=-8.73705+8.024782 \mathrm{X}$ & 1,0 & 0,51 \\
\hline Phytopathogenic & R. solani & $\mathrm{Y}=0.943564+2.171388 \mathrm{X}$ & 0,90 & 0,74 \\
fungi & S. rolfsii & $\mathrm{Y}=2.333924+1.797774 \mathrm{X}$ & 0,86 & 0,30 \\
& Collectotrichum spp & $\mathrm{Y}=2.953501+1.19974 \mathrm{X}$ & 0,89 & 0,51 \\
& P. capsici & $\mathrm{Y}=-1.50745+2.468208 \mathrm{X}$ & 0,95 & 4,33 \\
\hline
\end{tabular}

The results in Table 3 show that the $\mathrm{EC}_{50}$ value for Meloidogyne spp. juveniles decreases with increasing exposure time value prooving that the effectivity of neem cake increases with time.

The $\mathrm{IC}_{50}$ value shows that neem cake extracted solution inhibits the 4 fungi Rhizoctonia solani, Sclerotium rolfsii, Collectotrichum spp. and Phytophthora capsici. The neem cake extracted solution inhibits most strongly the growth of Sclerotium rolfsii $(0,30 \%)$ and is less effective towards the growth of Phytophthora capsici (4,33\%).

\section{Conclusion}

This research demonstrated that Ninh Thuan neem cake extracted solution has high ability to control the Meloidogyne spp. second stage juveniles and can inhibit the growth of 4 phytopathogenic fungi in black pepper (Piper nigrum L.). The results also show that these neem cakes contain bioactive substrates. Those substrates are considered as main factors to control nematodes and fungi in the black pepper plants.

\section{Acknowledgement}

The authors thank to the Ho Chi Minh Department of Science and Technology for financial support to complete this research. We also thank to Dr. Vu Van Do, Department of Bioactivity Substrates for providing neem cake material and Dr. Le Dinh Don, Department of Plant Protection-University of Agriculture and Forestry for his kindness to give us four kinds of fungi parasite in the pepper plant.

\section{References}

[1] Adegbite A.A., and S.O.Adesiyan. 2005. Root extracts of plants to control root-knot nematode on edible soybean. World Journal of Agricultural Sciences, 1(1), IDOSI Publications, 18-20.

[2] Coventry, E. and Allan E.J. 2001. Microbiological and chemical analysis of neem (Azadirachta indica) extracts: New data on antimicrobial activity. Phytoparasitica 29:5, 441-450. 
[3] Coyne D.L., J.M. Nicol and B. Claudius-Cole. 2007. Practical plant nematology: A field and laboratory guide, SP-IPM Secretariat, International Institute of Tropical Agriculture (IITA), Cotonou, Benin. 82 pp.

[4] Farooq A. Shah, M. Gaffney, M.A. Ansari, M. Prasad, T.M. Butt. 2008. Neem seed cake enhances the efficacy of the insect pathogenic fungus Metarhizium anisopliae for the control of black vine weevil, Otiorhynuchs sulcatus (Coleoptera: Curculionidae), Biological Control, 44, 111-115.

[5] Jeyarajan R., 1987. Effect of neem and other plant products in the management of plant diseases in India, Proc. $3^{\text {rd }}$ Int. Neem Conf., Nairobi, Kenya, 635644.

[6] Keshav Singh, Ajay Singh, D.K. Singh. 1996. Molluscicidal activity of neem (Azadirachta indica A.Juss), Journal of Ethnopharmacology, 52, 35-40.

[7] Muhammad Abid. 1996. Studies on the control of root knot nematodes (Meloidogyne spp.) with botanical toxicants, Thesis of PhD. in Nematology, University of Karachi, Karachi-75270, Pakistan. 194 pp.

[8] Musabyimana T., and R.C. Saxena. 1999. Efficacy of Neem Seed Derivatives against Nematodes Affecting Banana, Phytoparasitica, 27 (1), 43-49.

[9] Nazir Javed. 2008. Efficacy of neem (Azadirachta indica) formulations on biology of root-knot nematodes (Meloidogyne javanica) on tomato, Crop Protection, 27, 36-43.

[10] Nazir Javed, S.R. Gowen, M. Inam-ul-Haq, K. Abdullah, F. Shahina. 2007. Systemic and persistent effect of neem (Azadirachta indica) formulations against root-knot nematodes, Meloidogyne javanica and their storage life, Crop Protection, 26, 911-916.

[11] Nazir Javed, S.R. Gowen, M. Inam-ul-Haq, S.A. Anwar. 2007. Protective and curative effect of neem (Azadirachta indica) formulations on the development of root-knot nematode Meloidogyne javanica in roots of tomato plants, Crop Protection, 26, 530534.

[12] Nguyen Lan Dung. 1979. Research methods of mi- crobiology. Book II, Science and Technics Publish House, Hanoi, Vietnam.

[13] Nguyen Ngoc Chau. 2003. Plant parasitic nematodes and their control basic methods. Science and Technics Publish House, Hanoi, Vietnam. 302 pp.

[14] Nguyen Ngoc Kieng. 1992. Essential methods in science research. Ho Chi Minh City Publish House, Ho Chi Minh City, Vietnam. 137 pp.

[15] Nic Smol, 2005. General Techniques. Course notes International Nematology Course, Ghent Univeristy, Belgium. 35 pp.

[16] Ramarao P., Usharaja. 1983. Effect of organic amendments in soil on foot and root rot of wheat caused by Sclerotium rolfssi, Indian Phytopath., 36, 196-197.

[17] Randhawa N.S, B.S. Parmar. 1996. Neem, India and New Age International (P) Limited, ISBN: 81-2240973-3. $332 \mathrm{pp}$.

[18] Sartaj A. Tiyagi \& M. Mashkoor Alam. 1995. Efficacy of oil-seed cakes against plant-parasitic nematodes and soil-inhabiting fungi on mungbean and chickpea, Bioresource Technology, 51, 233-239.

[19] Singh R., and Vyas K.M. 1984. Influence of certain oil cakes on betelvine Phytophthora, Indian Phytopath., 37, 359-361.

[20] $\mathrm{Vu}$ Dang Khanh. 2003. Investigating anti-fungal activity of neem seed kernel extracts from neem (Azadirachta indica A. Juss) tree grown in Vietnam on some plant pathogens. MSc thesis. University of Natural Sciences, Ho Chi Minh City, Vietnam. 79 pp.

[21] Vu Trieu Man and Le Luong Te. 1998. The course of agricultural plant diseases. Book, Agri. Publ. House. Hanoi, Vietnam.

[22] Vu Van Do. 2007. Extraction, purification bioactive compounds of neem seed kernel from neem ( $\mathrm{Aza}$ dirachta indica A. juss) tree grown in Vietnam. Thesis of PhD. in Biology, Institute of Tropical Biology, Vietnamese Academy of science and Technology, Ho Chi Minh City, Vietnam. 113 pp. 